\title{
Energy Analysis of Small-Scale Ethanol Production from Cassava: A Case Study of the Cassakero Project in Nigeria
}

\author{
Elijah I. Ohimain*
}

\author{
Bioenergy and Environmental Biotechnology Research Unit, Biological Sciences Department, Faculty of \\ Science, Niger Delta University, Wilberforce Island, Bayelsa State, Nigeria
}

\begin{abstract}
The Federal Government of Nigeria recently announced the replacement of kerosene household cooking fuel with ethanol produced from cassava feedstock. The project was called "cassakero". The cassakero project aims to install 10,000 units of small-scale bio-ethanol refineries, operated by small-scale agro-processors across the country. The aim of this article is to present the results of an energy analysis of the ethanol cooking fuel produced from cassava feedstock by small-scale processors under Nigerian conditions Results show that for small-scale cassava ethanol production with the use of agrochemicals is: $11.61 \mathrm{MJ} / \mathrm{l}$ for total energy input, a Net Energy Ratio of 1.20, $2.29 \mathrm{MJ} / \mathrm{l}$ for Net Energy Gain, and $11.01 \mathrm{MJ} / \mathrm{l}$ for Net Renewable Energy Value. Without the use of agrochemicals ethanol production is $10.38 \mathrm{MJ} / \mathrm{l}$ for total energy input, a Net Energy Ratio of 1. 34, 3.52 MJ/l for Net Energy Gain, and $12.25 \mathrm{MJ} / \mathrm{l}$ for Net Renewable Energy Value. This is the first time that energy analysis has been carried out for small-scale cassava ethanol production under Nigerian conditions.
\end{abstract}

Keywords: Bioethanol, biofuel, cassakero, cooking fuel, energy analysis, kerosene substitution, renewable energy.

\section{INTRODUCTION}

The Federal Government of Nigeria (FGN) in November 2009 announced the replacement of kerosene (paraffin) household cooking and lighting fuel with ethanol produced from cassava feedstock in a project called cassakero. The replacement of paraffin created an immediate demand of 3.75 billion litres of ethanol per annum [1]. Since 2007 when Nigeria entered the biofuel race by releasing her national policy on biofuel [2], the current ethanol demand for the implementation of E10 policy and replacement of cooking paraffin is 5.14 billion litres per annum [3]. The country has a total installed capacity for ethanol production of about 134 million litres per annum [3, 4]. Currently, not all the plants are fully operational. The bulk of the current production is produced by Alconi/Nosak, UNIKEM and Intercontinental Distilleries (118.6 million litres representing nearly $90 \%$ of the total production) which rely on imported crude ethanol precursors from Brazil. Only the Allied Atlantic Distilleries Ltd, which commenced operations in 1999, is producing 30,000 litres per day of ethanol from locally sourced cassava feedstock [3].

Since the National policy on Biofuels was released in 2007, about 20 large-scale integrated bio-ethanol projects have been announced [3, 4]. There are potential benefits to the communities, including opportunities for employment, business and other

*Address correspondence to this author at the Bioenergy and Environmental Biotechnology Research Unit, Biological Sciences Department, Faculty of Science, Niger Delta University, Wilberforce Island, Bayelsa State, Nigeria; Tel/Fax: 234-803-7306520; E-mail: eohimain@yahoo.com non-farm benefits. However, there are several challenges associated with large scale bio-ethanol plants, such as depriving the rural community of their agricultural land, and domination of smallholder farmers and processors [5]. Malik et al. [6] reported that large-scale bio-ethanol factories dominate the Asia markets, while the smallholder ethanol processors face the risk of being neglected. A similar challenge is beginning to emerge in Nigeria as well, yet the much orchestrated benefits of biofuel to the rural people are dependent on the full and active participation of smallholders. The small-scale processors are also constrained by lack of energy efficient technologies for ethanol conversion and financing of operations. More worrisome is that electricity in rural Nigeria, from where the smallholders operate, is grossly inadequate and of poor quality. Power interruptions occur several times in a day without any prior notice. Also, there are total blackouts for days and even months [7]. Worse still, some of the rural areas are not even linked to the national grid. Due to inadequate power generation and supply infrastructure, less than $45 \%$ of Nigerians are connected to the national grid [8].

The cassakero project aims to install 10,000 units of small scale bio-ethanol refineries across the entire country to produce the daily ethanol cooking fuel requirement for 4 million families. The initial target would be to establish 1,000 units of small-scale biorefineries to produce 400,000 litres of ethanol daily over the next year, which would be increased to 4 million litres within four years. The refineries would be established in rural areas to assure the steady supply of feedstocks. The project also involves the 
establishment of an out-growers-based feedstock supply system that will produce 8 million tonnes of cassava at an average yield of 20 tonnes/ hectare/year from 400,000 hectares nationwide. The feedstock supply alone could benefit over 250,000 cassava farmers across the country. The construction work of the first batch of small-scale ethanol refineries under this project has commenced in Edo State in three communities, Auchi, Benin and Ehor [3].

Energy balance analysis is used to assess fuel performance. Leng et al. [9] reported that energy conversion efficiency is a key indicator to evaluate the eco-performance of a renewable energy source. Fuel conversion requires material and energy input such as water, feedstock, electricity, agrochemicals (fertilizer, pesticides) etc. The process of energy conversion generates air emissions including greenhouse gases, solid wastes and liquid effluents. Except these issues are carefully addressed in a balanced manner, the ecoperformance of biofuels could be jeopardized. The energy balance of ethanol is the difference between the energy content of ethanol and the energy input for the production of the ethanol fuel [10], which is also referred to as net energy gain (NEG) or net energy value (NEV) by other authors [11-13]. But energy balance analysis also includes other indices such as net energy ratio (NER). NER is the ratio of the energy content of the fuel to the energy input for the production of the fuel. NER is used to compare the energy balance of different fuel systems /feedstocks. NER values above 1 indicate positive energy balance i.e. energy savings, while values below 1 indicate negative energy balance. However, some authors have reported the limitations of NER and NEV as indicators of energy conversion efficiency. Nguyen et al. [10] suggested a better indicator, net renewable energy value (NREV) as an appropriate instrument to assess energy balance. Notwithstanding the importance of energy analysis, none has been carried out for small-scale ethanol production in Nigeria. This is the main thrust of this study. This research could therefore be beneficial to energy researchers, policy makers and the biofuel industry at large.

\section{METHODOLOGY}

The methodology used in this study is based on the ISO 14040:2006 and ISO 14044:2006, but limited to energy balance analysis (input and output).

\subsection{Goal and Scope Definition Including Assumptions and Limitations}

In line with ISO 14040:2006/14044:2006 requirements; the functional unit of this study is 1 litre of $50 \%$ ethanol (low concentration ethanol) produced from cassava feedstock (the rest $50 \%$ is made of water). During the study, primary data were collected from cassava farmers, flour processing centres, and small scale ethanol conversion distilleries. Literature sources for the various energy conversions for the various inputs are shown in Table 1.

\subsection{Energy Analysis}

Ethanol production from cassava feedstock involves four major steps: cassava cultivation, cassava tuber processing to flour, cassava flour conversion to

Table 1: Data Sources and Energy Conversions (Dry Weight)

\begin{tabular}{|c|c|c|c|c|}
\hline & Energy sources & units & Energy, MJ/unit & References \\
\hline \multirow[t]{8}{*}{ Inputs } & Seed stem & $\mathrm{kg}$ & 14 & {$[14]$} \\
\hline & NPK fertilizer & $\mathrm{kg}$ & 111 & {$[15]$} \\
\hline & Organic fertilizer & $\mathrm{kg}$ & 0.28 & [16] \\
\hline & Herbicide & $\mathrm{L}$ & 53.4 & {$[15]$} \\
\hline & Diesel & L & 56.31 & {$[17-21]$} \\
\hline & Gasoline & $\mathrm{L}$ & 31.2 & [22] \\
\hline & Wood & $\mathrm{kg}$ & 18 & [14] \\
\hline & Electrical energy & kwh & 3.6 & {$[10,17,18,23]$} \\
\hline \multirow[t]{4}{*}{ output } & Stem & $\mathrm{kg}$ & 14 & {$[14]$} \\
\hline & Tubers & $\mathrm{kg}$ & $19 \cdot 10$ & [24] \\
\hline & Peelings, bagasse, pulp & $\mathrm{kg}$ & $19 \cdot 10$ & {$[24]$} \\
\hline & Biogas & $\mathrm{kg}$ & 15.6 & [25] \\
\hline
\end{tabular}


ethanol, and transportation of raw materials and products. The detailed discussion of each stage can be found in Ohimain [5], while a summary of the cassava ethanol value chain including energy and material input is presented in section 2.2.1.

\subsubsection{Energy and Material Input}

Energy and material input for cassava ethanol include fertilizers (NPK and compost), agrochemicals (especially herbicides), fuel for transportation, and electricity for cassava processing and ethanol conversion. The planting material (seed) for cassava cultivation is the stem. Cassava stem used as planting materials is typically obtained from farm wastes during harvest. About $10 \%$ of total stem produced is used for planting purposes. Because of poor storability of cassava stem, unlike cereal grains, the usual practice is to prepare a new cassava farm ready for planting in time to coincide with harvest in order to maintain the viability of the stems. About 60 bundles of $100 \mathrm{~cm}$ long cassava stems (cut to $25 \mathrm{~cm}$ ) are required to plant one hectare.

Another vital input to cassava farming in Nigeria is fertilizer. Typically, the average farmer uses mostly organic fertilizer produced from the compost of the previous harvest. In cassava farms, this consists of $90 \%$ of the stems, leaves, and peelings if the cassava is processed at the farm. Fadare et al. [26] estimated the energy requirement for the production of organic compost in Nigeria to be $0.28 \mathrm{MJ} / \mathrm{kg}$. Similarly, Erdal et al. [27] and Kizilaslan [17] reported an energy conversion value of $303.10 \mathrm{MJ} /$ tonne of organic compost, which translated to about $0.3 \mathrm{MJ} / \mathrm{kg}$. It is known that organic compost is poor in minerals, particularly phosphate and potassium; hence NPK is sometimes used by a few farmers, while the majority of farmers embark on shifting cultivation. About $100 \mathrm{~kg}$ of nitrogen, $50 \mathrm{~kg}$ of phosphate, and $50 \mathrm{~kg}$ of potash fertilizer are used to cultivate 1 ha cassava farm. Stout et al. [15] estimated the direct energy input for the production, packing, distribution, and application of NPK fertilizer in Africa to be $111 \mathrm{MJ} / \mathrm{kg}$. However, a more recent estimate by Kim and Dale [28] is used for this assessment.

An important component of cassava farming in Nigeria is weeding. The majority of farmers do not use any form of herbicide for weed control. During farm preparation, the cleared farm is burnt typically, which is less effective than the application of a total herbicide. Also, some weed seeds survive the fire treatment.
Farm burning has several detrimental effects including the loss of organic matter/compost, and carbon dioxide is released into the atmosphere instead of being fixed in the soil as inorganic carbon. Also, fire can be detrimental to important soil flora and microorganisms, which are essential in nutrient cycle and sustenance of soil fertility. On the other hand, total herbicide treatment can also have detrimental effects on non-target soil organisms, and has the capacity to contaminate water sources $[29,30]$. When total herbicide is not used during land preparation, it is recommended that a preemergent herbicide is used three days after planting. With the International Institute for Tropical Agriculture (IITA) recommended planting density of $1 \mathrm{~m} \times 1 \mathrm{~m}$, when fully grown, the cassava forms a dense canopy, which suppress further weed growth. Most rural farmers in Nigeria use neither pre- nor post-emergence herbicide; they weed the farms manually. Stout et al. [15] estimated the direct energy input for the production, packing, distribution and application of herbicides in Africa to be $8.3 \mathrm{MJ} / \mathrm{kg}$. This we considered as too low because of the values presented by other authors. For example, Kim and Dale [28] used 429.27 MJ/kg, while Ozkan et al. [19] and Erdal et al. [22] used a conversion of $238 \mathrm{MJ} / \mathrm{kg}$. In view of all these, we therefore opt to use $429.27 \mathrm{MJ} / \mathrm{kg}$ for computation. The use of tractors in Nigerian farms is still not widespread, but manual energy is the common practice.

There have been conflicting reports about the average national yield of cassava tubers produced in Nigeria. The Food and Agricultural Organization [31, 32] recorded 10.8 tonnes/ha, which is the value that most other researchers are reporting for Nigeria [33]. Other studies have reported a wide range of values. The National Bureau of Statistics [34] reported 12 tonnes/ha. From field studies, Nweke et al. [35] reported a yield of 13.41 tonnes/ha and 19.44 tonnes/ha for local and improved cassava varieties respectively even without the use of inorganic fertilizer. Field data collected from the south-south geo-political zone during the period 2000-2002, shows that yield of cassava ranges from 9.39-15.93 tonnes/ha with an average of about 12 tonnes/ha, which has now increased to 25 tonnes/ha with the adoption of improved varieties and modern agronomic practices [36]. Okaiyeto and Lamidi [37] reported that the use of improved cassava cultivars has boosted yields in the range of 25-40 tonnes/ha. Therefore, the cassakero project targeting 20 tonnes/ha is in line with current practices. Cassava tuber has a gross energy of 19.10 $\mathrm{MJ} / \mathrm{kg}$ [24]. 
The conversion of electrical energy is consistent in literature. A value of $3.6 \mathrm{MJ} / \mathrm{KWh}$ is widely reported $[10,17,18,23]$. Notwithstanding, after accounting for losses during electricity generation in Nigeria and the Nigerian electricity mix, a factor of 7.387 was used for electricity conversion. In Nigeria, farms are located typically in rural areas far away from the national grid, and electrical energy is typically not used. However, electrical energy is a major input both in the cassava processing centre and ethanol conversion plants. Electricity supply in Nigeria is poor, unstable and unreliable; therefore most manufacturers resort to the use of gasoline and diesel powered generators [7]. Adenikinju [38] reported that self generated electricity accounted for $42 \%$ of total electricity in Nigeria. The Nigerian energy grid mix consists of $64.4 \%$ of the electricity produced from petroleum, and $35.6 \%$ from hydropower (Table 2). In this study, hydropower is considered a renewable source of energy and excluded the potential environmental impacts associated with river damming.

The energy used for the processing of $1000 \mathrm{~kg}$ cassava feedstock to flour is $346.40 \mathrm{MJ}$ [40]. It should be noted that the energy from sunlight, which is used for the drying of cassava flour, is considered free. Typically, for every tonne of cassava tuber processed about $250 \mathrm{~kg}$ flour is obtained, though Jekayinfa and Olajide [40] reported $200 \mathrm{~kg} /$ tonne, but other reports, including Nweke et al. [35], Knipscheer et al. [41], Philips et al. [32], and unpublished data from a cassava processing centre (Rohi Biotechnologies Ltd, Igarra cassava factory, Edo State, Nigeria), shows $250 \mathrm{~kg}$ cassava flour per tonne of raw cassava tuber. Hence, $250 \mathrm{~kg}$ flour is used for material and energy balance computations. Wastes produced per tonne of cassava tuber are cassava peelings $(100 \mathrm{~kg})$ and effluent water (650 litres). Balogun and Bawa [24] reported that cassava peels made up $11.8 \%$ of the tuber, in most cases it is $10 \%$, which is what we used in computations in this paper. Jekayinfa and Olajide [40] reported 680 litres of waste water is produced per tonne of cassava tuber.
The processing of $250 \mathrm{~kg}$ cassava flour to ethanol involves the input of $220 \mathrm{~g}$ each of $\sigma$ amylase and glucosidase enzymes. About $50 \mathrm{~kg}$ of yeast produced from previous fermentation process is typically recycled into the fermentation broth. Also, $220 \mathrm{~g}$ of triple superphosphate and $20 \mathrm{~g}$ of magnesium sulphate are added to the fermentation broth. The energy input for the production of these salts is considered insignificant because only trace amounts are used in the composition of the fermentation broth. About 1074 litres of water is added and at the end of the fermentation and distillation about 274 litres of low concentration ethanol is produced along with $90.5 \mathrm{~kg}$ of carbon dioxide, 1095.5 litres of wastewater, and $32.5 \mathrm{~kg}$ (dry weight) of solid waste containing yeast and cassava fibre/pulp. The solid waste containing yeast, which is commonly referred to as dried distillers grain with soluble (DDGS), is a good human and animal feed material because of the high protein content. In Thailand, about $10-15 \%$ of the original root weight ends up as solid wastes after cassava starch processing, which contained $68 \%$ residual starch and $27 \%$ fibre on a dry weight basis [42], 2000), and with the incorporation of yeast after fermentation, it becomes an excellent feed material. Attempts have been made to produce several useful products from cassava bagasse including organic acids, flavour and aroma compounds, and mushrooms using solid state fermentation [43].

For every litre of ethanol produced, electricity is required for fermentation (about $9 \mathrm{KWh}$ ), for distillation ( $3 \mathrm{KWh}$ ), and dehydration and other functions including denaturation and conversion of ethanol to cooking fuel (20 KWh) [44]. This adds up to $115.2 \mathrm{MJ}$ per tonne of raw cassava tuber, which also translates to $0.84 \mathrm{MJ}$ per litre of ethanol produced. In rural Nigeria, about 6.4 $\mathrm{kg}$ of hardwood is used to directly fire the fermenters and makeshift distiller/boilers to produce concentrated ethanol. In Brazil, it has been reported that $1.9 \mathrm{~kg}$ of fuel wood is required to produce $7 \mathrm{~kg}$ of steam per litre of ethanol [44], whereas in the US, $2 \mathrm{~kg}$ of wood is used [45]. The small-scale distillation of ethanol is a

Table 2: Nigerian Electricity Mix and their Renewability

\begin{tabular}{|c|c|c|}
\hline Source & \% contribution & Renewability \\
\hline \hline Gas & 39.8 & Fossil /non renewable \\
\hline Hydropower & 35.6 & Renewable \\
\hline Oil & 24.8 & Fossil /non renewable \\
\hline Coal & 0.4 & Fossil /non renewable \\
\hline
\end{tabular}

Source: Ikeme and Ebohon [39]. 
long tradition in rural Nigeria involving the use of makeshift rudimentary equipment and fuel wood as the energy source for the production of traditional alcoholic beverages from fermented oil palm and raffia palm juice (Figure 1). This equipment, often with limited process controls is unable to produce anhydrous ethanol, but it is able to distil ethanol to $50-70 \%$. It saved energy required for the partial distillation to $50 \%$ and will not require subsequent dehydration stages. Only about $0.45 \mathrm{~kg}$ of wood is required (per litre of ethanol produced) for the partial distillation for the production of low concentration ethanol. In India, low concentration cooking fuel running on $50 \%$ ethanolwater mixture has been developed and used in rural household cooking fuel [46-48].

Cassava processing wastes in addition to peels include stillage and effluents having a high BOD and COD, which are now commonly treated and used for biogas production. Using cassava peels only yielded $2.29 \mathrm{~L} /$ mass of slurry, while in combination with animal wastes such as cow dung in a ratio $1: 1$ yielded 4.88 $\mathrm{L} / \mathrm{mass}$ [25]. In Thailand, a cassava processing factory generates about $16.5 \mathrm{~m}^{3}$ of biogas, which is equivalent to $10.25 \mathrm{~m}^{3}$ of methane per cubic meter of wastewater [49]. The heating value of biogas is $15.6 \mathrm{MJ} / \mathrm{l}$ [25], or $22 \mathrm{MJ} / \mathrm{m}^{3}$ [50], whereas the heating value of methane, which made up about $60 \%$ of the biogas produced from cassava wastes, is $35.9 \mathrm{MJ} / \mathrm{m}^{3}$ [49].

\subsubsection{Transportation Energy}

Diesel fuel is used by trucks for the transportation of cassava farm produce, flour and ethanol. Gasoline powered light vehicles (2 tonnes capacity) are also used, especially for the transportation of farm produce to the market or cassava processing centres. Ten tonne diesel powered truks are used to convey ethanol to the blending plants located in the depots. The energy input for diesel production is one of the few input values that are consistent in the literature; a value of $56.31 \mathrm{MJ} / \mathrm{l}$ is widely reported [17-21]. The energy content of gasoline is $31.2 \mathrm{MJ} / \mathrm{L}$ [22].

Energy input for the transportation of cassava tubers to processing centres and ethanol conversion centres, and for the distribution of ethanol cooking fuel was estimated based on unpublished data from a cassava processing company (Rohi Biotechnologies Ltd.) and was used in the assessment. Cassava processing centres are located relatively close to cassava farms, within distances less than $10 \mathrm{~km}$. Nigeria is a large country of about one million square $\mathrm{km}$. Hence, with the planned establishment of 10,000 units of small-scale ethanol refineries nationwide, the

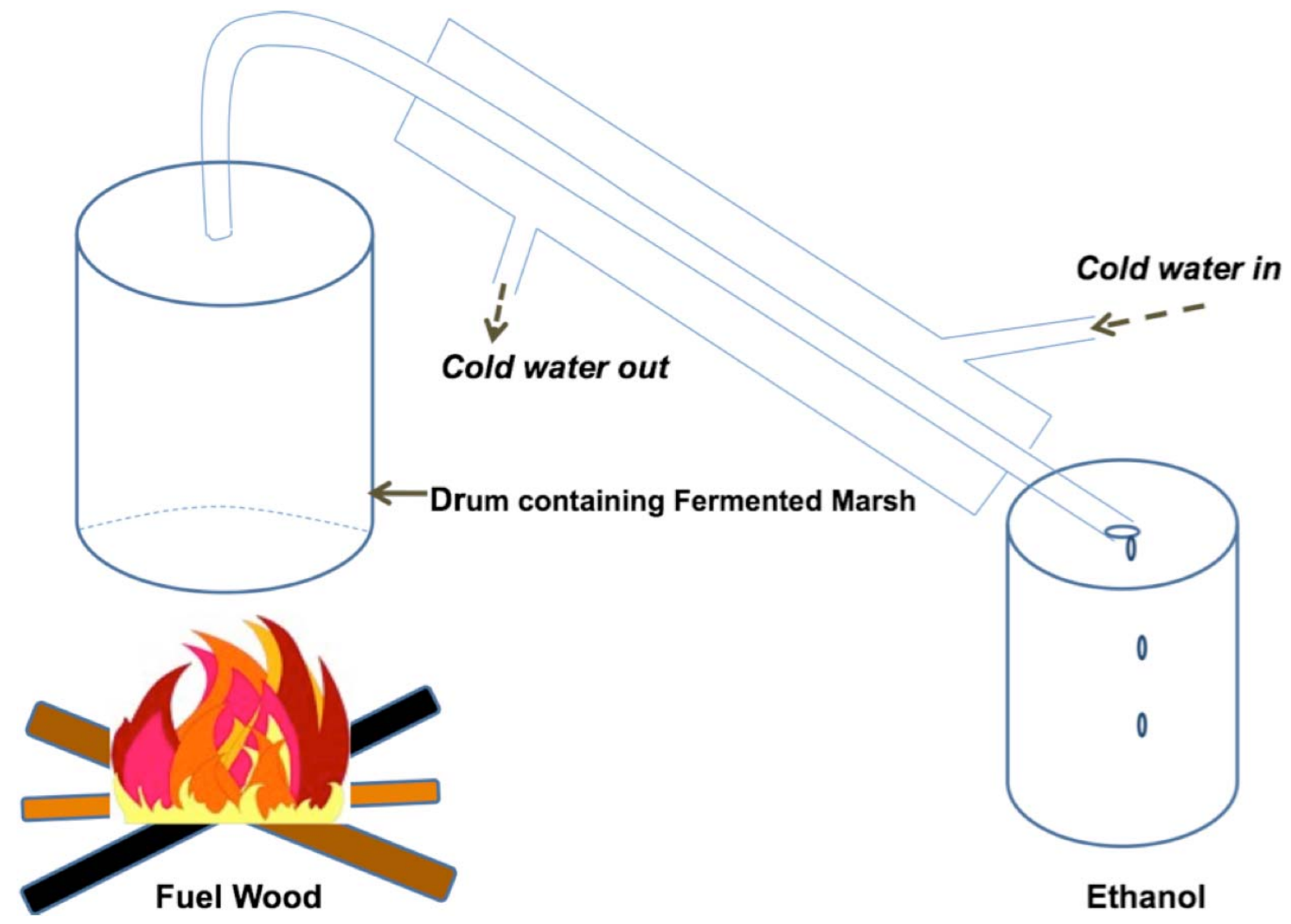

Figure 1: Small-scale distillation of ethanol using rudimentary equipment. 
travel distance to these ethanol conversion centres will be about $100 \mathrm{~km}$. Fuel consumption in Nigeria is an average of $9 \mathrm{~km} / \mathrm{l}$ of fossil fuel for light trucks [51] and $3.5 \mathrm{~km} / \mathrm{l}$ for 10 tonne diesel trucks [13], hence about 1.11 litres of gasoline will be consumed for transporting cassava from farms to the processing centres. 56.31 litres of diesel for the transportation of cassava flour to ethanol conversion centres. Another 56.31 litres will be consumed during the transportation ethanol from ethanol conversion centres to the nearest depot, and for the distribution of ethanol fuel to customers.

\subsubsection{Energy Balance Computation}

This assessment is based on the energy input for the production of $1 \mathrm{~L}$ of $50 \%$ ethanol compared to the energy contained in the ethanol itself, i.e. the heating value of ethanol. The following indicators were used to assess energy performance;

- $\quad$ Net Energy ratio (NER) = Energy output/ energy input [13], which is also referred to as fuel energy ratio (FER) in some literature [52]

- Net Energy gain (NEG), or net energy value $(\mathrm{NEV})=$ Energy output- Energy input [10-13]

- $\quad$ Net renewable energy value $(\mathrm{NREV})=$ Energy output- fossil Energy input [10,11]

- Energy resource conservation, percentage renewable $=$ renewable energy inputs/total energy inputs * 100 [53]

The heating value of anhydrous ethanol is well documented in the literature as $23 \mathrm{MJ} / \mathrm{kg}$, or $21.2 \mathrm{MJ} / \mathrm{l}$ [13, 54, 55], though Dai et al. [11] reported $21.85 \mathrm{MJ} /$. Adeniyi et al. [56], under experimental conditions reported that the heating value of ethanol produced from cassava starch is $22 \mathrm{MJ} / \mathrm{kg}$. Robinson [57] reported that the energy content of low concentration ethanol is $19.6 \mathrm{MJ} / \mathrm{kg}$ at a density of $0.71 \mathrm{~kg} / \mathrm{l}$, which is equivalent to $13.9 \mathrm{MJ} / \mathrm{l}$. Ethanol will replace the current cooking fuel, kerosene, which has a high heating value $(\mathrm{HHV})$ of $46.2 \mathrm{MJ} / \mathrm{kg}(40.2 \mathrm{MJ} / \mathrm{l})$, and a low heating value $(\mathrm{LHV})$ of $43 \mathrm{MJ} / \mathrm{kg}(37.3 \mathrm{MJ} / \mathrm{l})$.

\section{RESULTS AND DISCUSSION}

Results of the energy analysis (Tables 3-5) show the total energy required to produce and distribute a litre of low concentration ethanol under Nigerian conditions by small-scale processors is $11.61 \mathrm{MJ}$ with agrochemical input, and 10.38 without agrochemicals, excluding credits from co-products (by-products and energy derived from cassava processing wastes e.g. spent yeast, biogas, fertilizer). In both scenarios, the ethanol conversion phase is the most energy intensive, accounting for $74.42 \%$ with agrochemical input, and $83.26 \%$ without. Raw cassava tuber processing to flour accounted for $9.63 \%$ with agrochemicals, and $10.78 \%$ without, of the total energy input. The cassava farming phase accounted for $10.83 \%$ and $0.25 \%$ of the total energy input in the scenario with and without agrochemical input respectively. The large difference in the energy input of the two scenarios is expected because agrochemicals represent the major source of energy input in farming systems. The results of this study are in line with other previous studies, where the ethanol conversion stage is the most energy intensive. For example, Papong and Malakul [13] recorded 24.92 $\mathrm{MJ}$ for the production of $1 \mathrm{~L}$ of cassava ethanol in Thailand, with the ethanol conversion stage accounting for over $77 \%$ of the total energy input. Other studies from Thailand and China recorded different input energy values for the production of 1 litre ethanol using cassava feedstock including $15.85 \mathrm{MJ} / \mathrm{l}$ [10], 16.732 $\mathrm{MJ} / \mathrm{l}$ [11], and $12.06 \mathrm{MJ} / \mathrm{l}$ [23]. In all these studies, the ethanol conversion stage is the most energy intensive.

Table 5 presents a breakdown of the various forms of energy input for the conversion of cassava tubers to ethanol. Direct energy in the form of gasoline, diesel, wood, and electricity accounted for nearly $90 \%$ of the total energy input in the scenario with agrochemicals, and $100 \%$ without. Indirect energy, which consists of energy used in the manufacturing of fertilizers and herbicides accounted for $10.61 \%$ in the scenario with agrochemicals, and absent in the scenario without agrochemicals. Renewable energy input, which consists of energy for the production of organic fertilizer, wood, and hydro-electricity, represents $75.13 \%$ of the total energy input in the scenario with agrochemicals, and $84.05 \%$ in the scenario without agrochemicals, whereas fossil energy accounted for the remainder energy input in both scenarios. Notwithstanding the high energy input, the results of the scenario with agrochemical input are 1.20 NER, 2.29 MJ// NEG, and 11.01 MJ/I NREV, whereas without agrochemical inputs they were $1.34 \mathrm{NER}, 3.52 \mathrm{MJ} / \mathrm{l}$ NEG, and 12.25 MJ/I NREV (Table 4).

These results show that the production of ethanol from cassava feedstock in Nigeria by smallholder is energy efficient, because the NER is greater than 1 even without allocation of credits to the co-products, which include biogas, fertilizer, and animal feed. This value is close to the results obtained by Nwanchukwu 
Table 3: Energy Input for the Production of One Litre Fuel Ethanol without Co-Products Allocation

\begin{tabular}{|c|c|c|c|c|c|c|}
\hline & & units & Energy, MJ/unit & input quantity & $\begin{array}{l}\text { Energy } \\
\text { use, } \mathbf{M J} / \mathbf{I}\end{array}$ & Renewability \\
\hline \multirow{3}{*}{ Cassava farming } & $\mathrm{N}$ fertilizer & $\mathrm{kg}$ & 32 & 100 & 0.58 & Fossil \\
\hline & K fertilizer & $\mathrm{kg}$ & 9.07 & 50 & 0.08 & Fossil \\
\hline & Organic fertilizer & $\mathrm{kg}$ & 0.28 & 500 & 0.03 & Renewable \\
\hline \multirow[t]{2}{*}{$\begin{array}{l}\text { Conversion to } \\
\text { ethanol }\end{array}$} & $\begin{array}{l}\text { Liquefaction, Saccharification and } \\
\text { fermentation }\end{array}$ & $\mathrm{kg}$ & 18 & 0.45 & 8.10 & renewable \\
\hline & $\begin{array}{l}\text { Denaturation and other functions } \\
\text { including water production, } \\
\text { wastewater treatment }\end{array}$ & kwh & 7.387 & 20 & 0.54 & mixed \\
\hline \multirow{2}{*}{ Transportation } & Diesel (Ethanol to depot) & 1 & 56.31 & 28.57 & 0.29 & Fossil \\
\hline & $\begin{array}{l}\text { Diesel (Distribution of fuel to } \\
\text { consumers) }\end{array}$ & I & 56.31 & 28.57 & 0.29 & Fossil \\
\hline TOTAL & & & & & 11.61 & \\
\hline
\end{tabular}

Table 4: Cassava Ethanol Processing Energy Share and Indices

\begin{tabular}{|c|c|c|c|c|c|c|c|}
\hline & & \multicolumn{3}{|c|}{$\begin{array}{c}\text { Scenario with inorganic fertilizer and } \\
\text { herbicides }\end{array}$} & \multicolumn{3}{|c|}{$\begin{array}{l}\text { Scenario without inorganic } \\
\text { fertilizer and herbicides }\end{array}$} \\
\hline & & $\begin{array}{c}\text { Energy } \\
\text { input, MJ/L }\end{array}$ & $\%$ & Indices & $\begin{array}{c}\text { Energy } \\
\text { input, } \\
\text { MJ/L }\end{array}$ & $\%$ & Indices \\
\hline \multirow{3}{*}{$\begin{array}{l}\text { Cassava } \\
\text { ethanol } \\
\text { processing } \\
\text { phases }\end{array}$} & Cassava farming (MJ/I) & 1.26 & 10.832 & - & 0.03 & 0.246 & - \\
\hline & Cassava processing (MJ/) & 1.12 & 9.634 & - & 1.12 & 10.778 & - \\
\hline & Transportation (MJ/I) & 0.59 & 5.112 & - & 0.59 & 5.719 & - \\
\hline \multirow{3}{*}{$\begin{array}{l}\text { Energy } \\
\text { indices }\end{array}$} & NER & - & - & 1.20 & - & - & 1.34 \\
\hline & NEG & - & - & 2.29 & - & - & 3.52 \\
\hline & NREV & - & - & 11.01 & - & - & 12.25 \\
\hline
\end{tabular}

Table 5: Form of Energy Input

\begin{tabular}{|c|c|c|c|c|c|}
\hline & & \multicolumn{2}{|c|}{$\begin{array}{c}\text { Scenario with inorganic } \\
\text { fertilizer and herbicides }\end{array}$} & \multicolumn{2}{|c|}{$\begin{array}{c}\text { Scenario without inorganic } \\
\text { fertilizer and herbicides }\end{array}$} \\
\hline Form of energy & Definition & $\begin{array}{c}\text { MJ/I of } \\
\text { ethanol }\end{array}$ & $\begin{array}{c}\% \text { of total } \\
\text { energy }\end{array}$ & $\begin{array}{c}\text { MJ/I of } \\
\text { ethanol }\end{array}$ & $\begin{array}{c}\% \text { of total } \\
\text { energy }\end{array}$ \\
\hline \hline Direct energy & diesel, gasoline, electricity, wood & 10.38 & 89.39 & 10.38 & 100.00 \\
\hline Indirect energy & inorganic fertilizers, herbicide & 1.23 & 10.61 & 0.00 \\
\hline $\begin{array}{c}\text { Renewable energy } \\
\text { hydro-electricity, wood energy, organic } \\
\text { fertilizer }\end{array}$ & $\begin{array}{c}8.72 \\
\text { Non- renewable } \\
\text { energy (fossil) }\end{array}$ & $\begin{array}{c}\text { Diesel, gasoline, herbicide, inorganic } \\
\text { fertilizer, electricity from petroleum }\end{array}$ & 2.89 & 24.87 & 8.72 \\
\hline Total energy* & & 11.61 & & 1.65 \\
\hline
\end{tabular}

*The total energy input is the sum of the fossil and renewable energy (or direct energy and indirect energy). 
and Lewis [14] on cassava ethanol production in Nigeria, which ranged from a NER of $1.1-1.4$ depending on the agronomic practices, with the ratio being lower under mechanized farming with the use of agro-chemicals than labour intensive farming without the use of agro-chemicals. Because the NER is close to 1.0 , the results suggest that the small-scale bioethanol production from cassava feedstocks is marginally energy efficient. Sanden and Karlstrom [58] advised that environmental assessments of emerging technologies should not only include effects resulting from marginal change of the current system, but should also consider marginal contributions to radical system change. The NEV can, however, be increased and optimized through the utilization of cassava processing wastes for energy and other useful purposes. In a recent study, Ohimain et al. [59] reported that huge volumes of wastes are generated during the processing of cassava tubers to garri (a toasted granule). The study revealed that only $34 \%$ of the raw cassava tubers are converted to garri, while wastes including liquid effluent, gaseous emissions and solid wastes accounted for the rest $66 \%$. Cassava peelings and bagasse can be used for the production of fertilizer [16], animal feed [24], or as fuel to run steam turbines for power generation [49]. Also, the cassava effluent and stillage generated can be converted to biogas via microbial anaerobic digestion [25]. Biogas can also be used as fuel for gas turbines for power generation [49]. Cassava processing wastes have been used as raw materials for several industrial applications for the production of mushrooms, single cell protein, enzymes, organic acids, amino acids, and other bulk chemicals [42].
Results of the sensitivity study that was carried out by increasing and decreasing all the input energy by $10 \%$ also reveal that the cassava ethanol is still efficient (Figure 2). Since most of the input data were obtained from literature, concerns over the uncertainties and possible errors have been raised. However, comparing the result to other studies shows a high level of agreement. Dai et al. [11] similarly obtained a net energy ratio of 1.545 , a net energy value of $7.475 \mathrm{MJ} / \mathrm{l}$, and a NREV of $7.881 \mathrm{MJ} / \mathrm{l}$ while working on cassava ethanol in China. Nguyen et al. [10] recorded a NEV of 8.8 and a NREV of $9.15 \mathrm{MJ} / \mathrm{l}$. Leng et al. [9] recorded a NER of 1.28. Papong and Malakul [13] recorded 1.11 for NER and $19.03 \mathrm{MJ} / \mathrm{l}$ for NEG.

Cassava is one of the most important food crops in Nigeria and the whole of Africa [35]. Nigerians consume cassava daily, with some people eating it more than once in a day [32]. Cassava use is increasing in Nigeria owing to Government policies that have focused on the industrialization of the crop for the production of animal feed, baking flour, and high fructose syrup. The emergence of cassava as a feedstock for the production of fuel ethanol could conflict with food resources, causing hike in food prices, which could benefit the rural farmers, but could be detrimental on human nutrition. Cassava is the cheapest source of food crop in terms of price/calories and was regarded as a hunger fighter and the last hope of the 'common man' [35]. This important feature of cassava is gradually eroding due to price increase as a result of the multiple uses of the crop. It should be noted that other countries such as Thailand, Brazil, and China, where cassava is used as feedstock for ethanol production, the crop is not their major staple.

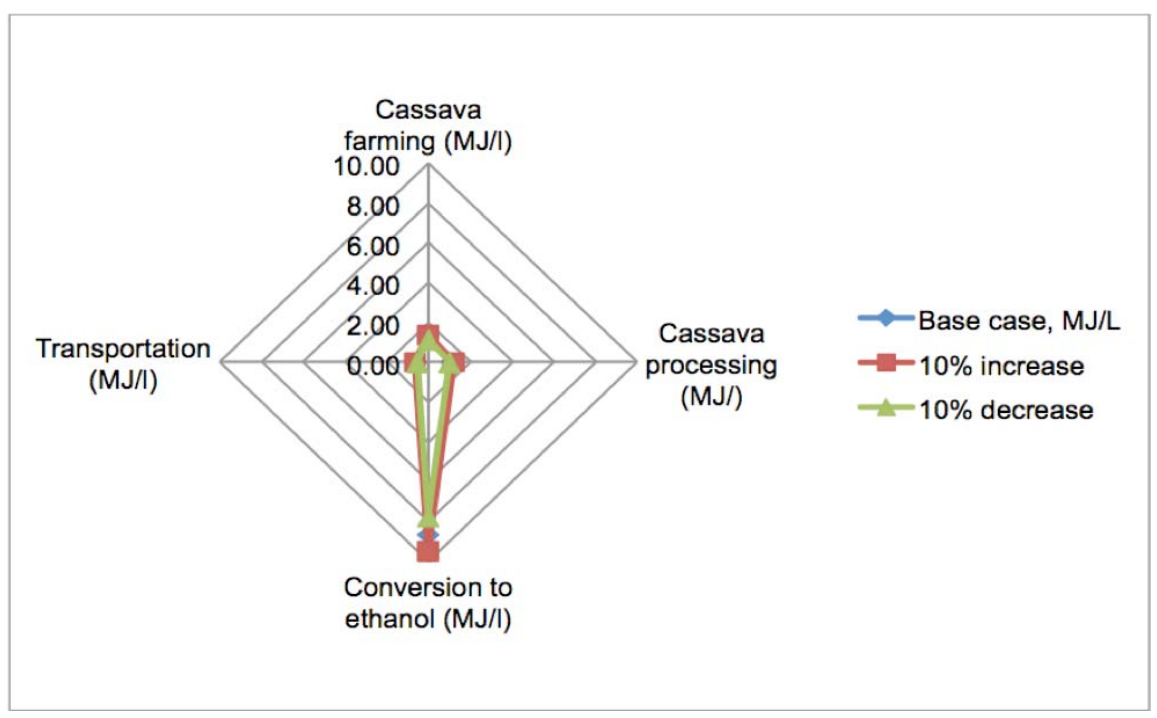

Figure 2: Sensitivity analysis of varying the input energy. 
Proponents of the cassakero project planned to establish 400,000 ha of new cassava farms in order to mitigate the potential food versus fuel effects that could arise when cassava is used for ethanol production in Nigeria. However, the expansion of cassava farms into forests, as a result of ethanol production could destroy virgin forests and wildlife, thus threatening sustainability and biodiversity. Ironically, interest in producing fuel ethanol from biomass is an attempt to make transportation and cooking fuel more sustainable [60]. Uilein et al. [61] reported that the utilization of renewable energy has led to ecological advantages compared to fossil fuel, but it has also come with ecological disadvantages, particularly with respect to intensive land use [62]. Though, farm mechanization and application of modern agricultural practices, have increased yield of cassava produced in Nigeria [63], it has also come with environmental challenges associated with agricultural intensification. Hence, there is the need for trade-off and balance between food, fuel, biodiversity, and sustainability. However, life cycle economic assessment of cassava ethanol production in China revealed that cassava fuel ethanol production is sustainable [64].

\section{CONCLUSION}

An energy analysis of ethanol production by smallholders in rural Nigeria was carried out. Results show that direct energy in the form of gasoline, diesel fuel, and electricity accounted for nearly $90 \%$ of the total energy input, while indirect energy accounted for $10.61 \%$ in the scenario with agrochemical input. Renewable energy input represents $75.13 \%$, whereas $24.87 \%$ of the energy input is fossil fuel in the scenario with agrochemical input. Smallholder cassava ethanol production, with the use of agrochemicals is the following: $11.61 \mathrm{MJ} / \mathrm{l}$ total energy input, $1.20 \mathrm{NER}$, 2.29MJ/I NEG, and 1101MJ/I NREV: while without the use of agrochemicals is: $10.38 \mathrm{MJ} / \mathrm{l}$ total energy input, and, 1.34 NER, 3.52MJ// NEG, and 12.25MJ/I NREV. This suggests that the scenario without the use of agrochemicals, as commonly practiced in Nigeria, is more energy efficient. However, without the use of agrochemicals farmers suffer the risk of lower ethanol production due to reduced crop yield of 10.8-12 tonnes/ha compared to 20tonnes/ha when agrochemicals are used for feedstock cultivation. This result is in agreement with other studies showing that the ethanol production in Nigeria is marginally energy efficient.

Notwithstanding the positive energy indices, ethanol production from cassava feedstocks by smallholder processors could face other challenges such as lack of funds, poor electricity, water and other social infrastructure and environmental challenges, which could threaten the eco-performance of ethanol fuel. For instance, during the production of gari (a roasted granule and the food product from cassava) by smallholder processors, the resulting solid and liquid wastes are freely discharged into the environment without any form of treatment. And due to weak environmental law enforcement, this practice has continued unabated. Also, the use of cassava feedstock for fuel production could compete with food sources, which could lead to hike in food prices resulting in malnutrition. Besides, the expansion of cassava farms into virgin forests could cause other environmental problems such as the release of trapped $\mathrm{CO}_{2}$, destruction of wildlife habitat and pollution of water sources especially if agrochemicals are applied. The use of wood for ethanol distillation could further threaten forests and associated wildlife. Except these aforementioned challenges are well addressed, the entrance of Nigeria into biofuel race could become unsustainable.

\section{ACKNOWLEDGEMENT}

The author wishes to thank Rohi Biotechnologies Ltd, and Sustainable Development Initiative, Port Harcourt, Nigeria for supporting this study. The author wishes to thank Prof. Marinus Otte and Dr. Jacob Donna of North Dakota State University, Fargo and the two anonymous reviewers for reviewing the manuscript.

\section{REFERENCES}

[1] Azih I. Biofuels demand: opportunities for rural development in Africa (Nigerian case study). Paper presented at the $2^{\text {nd }}$ European Forum on Sustainable Development, Berlin, Germany, 18-21 June 2007.

[2] NNPC. Draft Nigerian Bio-fuel policy and incentives. Nigerian National Petroleum Corporation, Abuja 2007.

[3] Ohimain El. Emerging bio-ethanol projects in Nigeria; their opportunities and challenges. Energy Policy 2010; 38: 71618. http://dx.doi.org/10.1016/i.enpol.2010.07.038

[4] Ohimain El. Evaluation of pioneering bioethanol projects in Nigeria following the announcement and implementation of the Nigerian biofuel policy and incentives. Energy Sources Part B 2012a; In press.

[5] Ohimain El. Environmental impacts of smallholder ethanol production from cassava feedstock for the replacement of kerosene household cooking fuel in Nigeria. Energy Sources Part A 2012b; In press.

[6] Malik US, Ahmed M, Sombilla MA, Cueno SL. Biofuel production for smallholder producers in the Greater Mekong Sub-region. Appl Energy 2009; 86: S58-S68. 
[7] Adenikinju AF. Electricity infrastructure failure in Nigeria: a survey-based analysis of the costs and adjustment responses. Energy Policy 2003; 31: 1519-30. http://dx.doi.org/10.1016/S0301-4215(02)00208-2

[8] Ibitoye FI, Adekinikinji A. Future demand for electricity in Nigeria. Appl Energy 2007; 84: 492-504. http://dx.doi.org/10.1016/j.apenergy.2006.09.011

[9] Leng R, Wang C, Zhang C, Dai D, Pu G. Life cycle inventory and energy analysis of cassava-based fuel ethanol in China. J Cleaner Prod 2008; 16: 374-84.

http://dx.doi.org/10.1016/j.jclepro.2006.12.003

[10] Nguyen TLT, Gheewala SH, Garivait S. Full chain energy analysis of fuel ethanol from cassava in Thailand. Environ Sci Technol 2007a; 41: 4135-42. http://dx.doi.org/10.1021/es0620641

[11] Dai D, Hu Z, Pu G, Li H, Wang C. Energy efficiency and potentials of cassava fuel ethanol in Guangxi region of China. Energy Convers Manage 2006; 47: 1686-99. http://dx.doi.org/10.1016/j.enconman.2005.10.019

[12] Gezer I, Acaroglu M, Haciseferogullari H. Use of energy and labour in apricot agriculture in Turkey. Biomass Bioenergy 2003; 24: 215-9.

http://dx.doi.org/10.1016/S0961-9534(02)00116-2

[13] Papong S, Malakul P. Life-cycle energy and environmental analysis of bioethanol production from cassava in Thailand. Bioresource Technol 2010; 101: S112-8. http://dx.doi.org/10.1016/j.biortech.2009.09.006

[14] Nwanchukwu CC, Lewis C. A net energy analysis of fuels from biomass: the case of Nigeria. Biomass 1986; 11: 27189. http://dx.doi.org/10.1016/0144-4565(86)90099-5

[15] Stout BA, Myers CA, Hurand A, Faidley LW. Energy for World Agriculture. Food and Agricultural Organization, Rome 1979.

[16] Fadare DA, Bamiro OA, Oni AO. Energy analysis for the production of powdered and pelletized organic fertilizer in Nigeria. ARPN J Eng Appl Sci 2009; 4(4): 75-82.

[17] Kizilaslan H. Input-output energy analysis of cherries production in Tokat Province of Turkey. Appl Energy 2009; 86: $1354-8$.

http://dx.doi.org/10.1016/j.apenergy.2008.07.009

[18] Ozkan B, Kurku A, Akcaoz H. An input-output energy analysis in greenhouse vegetable production: a case study for Antalya region of Turkey. Biomass Bioenergy 2004; 26 : 89-95.

http://dx.doi.org/10.1016/S0961-9534(03)00080-1

[19] Ozkan B, Fert C, Karadeniz CF. Energy and cost analysis for greenhouse and open field grape production. Energy 2007; 32: $1500-4$

http://dx.doi.org/10.1016/j.energy.2006.09.010

[20] Shahan S, Jafari A, Mobil H, Rafiee S, Karimi M. Energy use and economical analysis of wheat production in Iran: a case study from Ardabil province. J Agric Technol 2008; 4(1): 7788.

[21] Yilmaz I, Akcaoz H, Ozkan B. An analysis of energy use and input costs for cotton production in Turkey. Renewable Energy 2005; 30: 145-55. http://dx.doi.org/10.1016/j.renene.2004.06.001

[22] Nanaki EA, Koroneos CJ. Comparative LCA of the use of biodiesel, diesel and gasoline for transportation. J Cleaner Prod 2012; 20: 14-19. http://dx.doi.org/10.1016/j.jclepro.2011.07.026

[23] Nguyen TLT, Gheewala SH, Garivait S. Energy balance and GHG-abatement cost of cassava utilization for fuel ethanol in Thailand. Energy Policy 2007b; 35(9): 4585-96. http://dx.doi.org/10.1016/j.enpol.2007.03.012
[24] Balogun TF, Bawa GS. Cassava peels in the diet of young pigs in Nigeria. Tropical Anim Health Prod 1997; 29(4): 20915

http://dx.doi.org/10.1007/BF02632306

[25] Ofoefule AU, Uzodinma EO. Biogas production from blends of cassava (Manihot utilisima) peels with some animal wastes. Int J Physical Sci 2009; 4(7): 398-402.

[26] Fadare, DA, Bamiro OA, Oni AO. Energy analysis for the production of powdered and pelletized organic fertilizer in Nigeria. ARPN J Eng Appl Sci 2009; 4(4): 75-82.

[27] Erdal G, Esengun K, Erdal H, Gunduz O. Energy use and economical analysis of sugar beet production in Tokat province of Turkey. Energy 2007; 32: 35-41. http://dx.doi.org/10.1016/j.energy.2006.01.007

[28] Kim S, Dale BE. Cumulative energy and global warming impact from the production of biomass for biobased products. J Industr Ecol 2004; 7(3-4): 147-62.

\section{http://dx.doi.org/10.1162/108819803323059442}

[29] Luken JO, Belting SW, Kumler RL. Target/non-target effects of herbicides in power-line corridor vegetation. J Arboriculture 1993; 19: 299-302.

[30] Lindsay EA, French K. The impact of the herbicide glyphosate on leaf litter invertebrates within Bitou bush, Chrysanthemoides monilifera ssp rotundata infestation. Pest Managem Sci 2004; 60: 1205-12.

http://dx.doi.org/10.1002/ps.944

[31] FAO. The State of Food and Agriculture 2008: Biofuels: prospects, risks and opportunities. Food and Agricultural Organization, Rome, Italy 2008.

[32] Phillips TP, Taylor DS, Sanni L, Akoroda MO. A cassava industrial revolution in Nigeria; the potential for a new industrial crop. The Global Cassava Development Strategy. IFAD/ FAO, Rome 2004

[33] Naylor RL, Liska AJ, Burke MB, Falcon WP, Gaskell JC, Rozelle SD, Cassman KG. The ripple effect; biofuels, food security, and the environment. Environment 2007; 49(9): 3143.

\section{http://dx.doi.org/10.3200/ENVT.49.9.30-43}

[34] NBS (National Bureau of Statistics). Facts and figures 2008 http://www.nigerianstat.gov.ng/ Assessed 10 January 2010 2008.

[35] Nweke FI, Spencer DSC, Lynam JK. The Cassava Transformation: Africa's Best Kept Secrete. Michigan State University Press, East Lansing, USA 2002.

[36] Azaino E. Business opportunities in the cassava value chain in Nigeria. http://uptonvilleoginstu.org/cassava. htm, accessed 12 February 2010. 2008.

[37] Okaiyeto PO, Lamidi OS. Research and development in cassava production and ruminant nutrition in Nigeria: an overview. J Eng Appl Sci 2006; 1(2): 117-24.

[38] Adenikinju AF. Efficiency of the energy sector and its impact on the competitiveness of the Nigerian economy. Int Assoc Energy Econ 2008; Q1: 27-31.

[39] Ikeme J, Ebohon OJ. Nigeria's electric power sector reform what should form the key objectives? Energy Policy 2005; 33: 1213-21.

http://dx.doi.org/10.1016/j.enpol.2003.11.018

[40] Jekayinfa SO, Olajide JO. Analysis of energy usage in the production of three selected cassava-based foods in Nigeria. J Food Eng 2007; 82: 217-26. http://dx.doi.org/10.1016/j.jfoodeng.2007.02.003

[41] Knipscheer $\mathrm{H}$, Ezedinma $\mathrm{C}$, Kormawa $\mathrm{P}$, Asumugha $\mathrm{G}$, Makinde K, Okechukwu R, Dixon A. Opportunities in the industrial cassava market in Nigeria. International Institute for Tropical Agriculture, Ibadan, Nigeria 2007. 
[42] Sriroth K. Chollakup R, Chotineeranat S, Piyachomkwan K, Oates CG. Processing of cassava wastes for improved biomass utilization. Biores Technol 2000; 71: 63-9. http://dx.doi.org/10.1016/S0960-8524(99)00051-6

[43] Pandey A, Soccol CR, Nigam P, Soccol VT, Vandenberghe LPS, Mohan R. Biotechnological potential of agro-industrial residues. II; cassava bagasse. Biores Technol 2000; 74: 817. http://dx.doi.org/10.1016/S0960-8524(99)00143-1

[44] Moreira JR, Sierra GE. Alternative fuels: Brazilian outlook, In: Dessai AV, Ed. Alternative Liquid Fuels. New Age International Ltd Publishers, New Delhi, India 1990; pp. 8-87.

[45] Pimentel D, Patzek TW. Ethanol production using corn, switch grass and wood; biodiesel production using soya beans and sunflower. Nat Resour Res 2005; 14(1): 65-76. http://dx.doi.org/10.1007/s11053-005-4679-8

[46] Rajvanshi AK. Ethanol fuel for rural households. Nimbkar Agricultural Research Institute, Maharashtra, India. http://nariphaltan.virtualave.net/ruralethanol.pdf. Accessed 12 December 2009; 2006.

[47] Rajvanshi AK. Ethanol lantern cum stove for rural areas. Nimbkar Agricultural Research Institute, Maharashtra, India 2009.

[48] Rajvanshi AK, Patil SM, Mendonca B. Low concentration ethanol stove for rural areas in India. Energy for Sust Dev 2007; 11(1): 63-67.

[49] Plevin R, Donnelly D. Converting waste to energy and profit; tapioca starch power in Thailand. Ren Energy World. September-October Edition 2004; 74-81.

[50] Itodo IN, Agyo GE, Yusuf P. Performance evaluation of a biogas stove for cooking in Nigeria. J Energy in Southern Africa 2007; 18(3): 14-18.

[51] Ajao EA, Anurigwo S. Land-based Sources of Pollution in the Niger Delta, Nigeria Ambio 2002; 31(5): 442-45.

[52] Davis SC, Anderson-Teixeira KJ. Life-cycle analysis and the ecology of biofuels. Trends Plant Sci 2009; 14(3): 140-46. http://dx.doi.org/10.1016/j.tplants.2008.12.006

[53] Lavigne A, Powers SE. Evaluating fuel ethanol feedstocks from energy perspectives: a comparative energy assessment of corn and corn stover. Energy Policy 2007; 35: 5918-30. http://dx.doi.org/10.1016/j.enpol.2007.07.002

[54] Hu Z, Fang F, Ben D, Pu G, Wang C. Net energy, $\mathrm{CO}_{2}$ emission, and life-cycle cost assessment of cassava-based ethanol as an alternative automotive fuel in China. Appl Energy 2004a; 78: 247-56.

http://dx.doi.org/10.1016/j.apenergy.2003.09.003

[55] Hu Z, Pu G, Fang, F, Wang C. Economics, environment, and energy life cycle assessment of automobiles fuelled by bioethanol blends in China. Ren Energy 2004b; 29: 2183-92. http://dx.doi.org/10.1016/j.renene.2004.03.014

[56] Adeniyi OD, Kovo AS, Abdulkareem AS, Chuckwudozie C. Ethanol fuel production from cassava as a substitute for gasoline. J Dispers Sci Technol 2007; 28: 501-504. http://dx.doi.org/10.1080/01932690701276940

[57] Robinson J. Bio-ethanol as a household cooking fuel. A mini pilot study of the superblu stove in peri-urban Malawi. MSc Thesis, Loughborough University, Leics, UK 2006.

[58] Sanden BA, Karlström M. Positive and negative feedback in consequential life-cycle assessment. J Cleaner Prod 2007; 15(15): 1469-81.

http://dx.doi.org/10.1016/j.jclepro.2006.03.005

[59] Ohimain EI, Silas-Olu DI, Zipamoh JT. Biowastes Generation by Small Scale Cassava Processing Centres in Wilberforce Island, Bayelsa State, Nigeria. Greener J Environ Manag Public Safety 2013; 2(1): 51-59.

[60] Von Blottnitz H, Curran MA. A review of assessments conducted on bio-ethanol as a transportation fuel from a net energy, greenhouse gas, and environmental life cycle perspective. J Cleaner Prod 2007; 15(7): 607-19. http://dx.doi.org/10.1016/j.jclepro.2006.03.002

[61] Uihlein A, Ehrenberge S, Schebek L. Utilisation options of renewable resources: a life cycle assessment of selected products. J Cleaner Prod 2008; 16(12): 1306-20. http://dx.doi.org/10.1016/j.jclepro.2007.06.009

[62] Silalertruska T, Gheewala SH. Environmental sustainability of bioethanol production in Thailand. Energy 2009; 34: 1933-46. http://dx.doi.org/10.1016/j.energy.2009.08.002

[63] Nkakini SO, Ayotamuno MJ, Ogaji SOT, Probert SD. Farm mechanization leading to more effective energy utilization for cassava and yam cultivation in Rivers State, Nigeria. Appl Energy 2006; 83(12): 1371-25. http://dx.doi.org/10.1016/j.apenergy.2006.03.001

[64] Zhang C, Han W, Jing X, Pu G, Wang C. Life cycle economic analysis of fuel ethanol derived from cassava in southwest China. Renewable Sustainable Energy Rev 2003: 7: 353-66. http://dx.doi.org/10.1016/S1364-0321(03)00057-1 